\title{
Some Periglacial Morphology in the Sagarmatha (Everest) Region, Khumbu Himal*
}

\begin{abstract}
Shuji Iwata**
Abstract

The periglacial morphology in the Sagarmatha region, Khumbu Himal, was surveyed and mapped. Below the snow line most of the mountain slopes consist of rock walls, talus, and block slopes. The rock detritus is produced by frost action and other weathering processes and transported downward as rock falls. Rock glaciers and block streams are produced where the periglacial process acts strongly and not only the rock debris but also snow and ice concentrate. The block slopes occupy the gentle valley side slopes which are covered with coarse and angular rock fragments mass-wasting from bed rock. Vegetated patterned ground develops over a large area because dense winter freezing acts over the vegetation fed by monsoon rain and high temperature in summer. Sorted patterned ground is rare in the region and is found only at the bare ground area adjacent to the glaciers and the bottoms of ponds. Some forms, such as debris islands, rock glaciers, and block slopes in the region are inactive at present.
\end{abstract}

\section{Introduction}

Though the improtance of periglacial environments in the slope development of the Himalayas was well discussed by Kar (1969) for the Sikkim and Darjeeling Himalayas, no study of the periglacial forms has been carried out in the Nepal Himalayas. In this paper, the writer reports some of the periglacial landforms and phenomena in the Sagarmatha (Everest) region, Khumbu Himal. The area investigated is Imja basin which is one of the tributaries of Dudh Kosi, above $4000 \mathrm{~m}$ in altitude.

It shows a typicalal pine landscape; high peaks with existing glaciers surround wide troughs occupied by debris-covered glacier terminus and moraines.

The Sagarmatha region is included in the zone of granite and gneiss (Gansser, 1964; Ohta and Akiba, 1973). Light-coloured granite is exposed on the upper flanks of Mt. Sagarmatha and Lhotse, rising up toward the north, and most of the region is composed of dark-coloured gneiss. Along the boundary zone of the granite and the gneiss, folded schist and slate veins are formed.

* Glaciological Expedition to Nepal, Contribution No. 24.

** Graduate School, Tokyo Metropolitan University, Setagaya-ku, Tokyo 158
The characteristic features of the climate are relatively warm and humid summer, and winter is so severe that the freeze-thaw period at Lhajung Station $(4420 \mathrm{~m})$ reaches 190 days. Snow line lies at an altitude of $5600-6000 \mathrm{~m}$ in the dry postmonsoon season.

As the area investigated lies wholly above forest

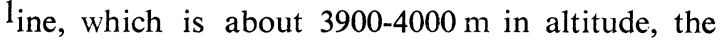
valley slopes and moraines below $5000 \mathrm{~m}$ are covered with rhododendron and juniperous shrub and grass vegetation. Above this zone the terrain is covered with dense but short grass like a cushion. The vegetation above the forest line has been classified into five groups according to the altitude, slope direction, and topographical conditions (Haffner, 1972).

The periglacial landforms and phenomena around the Lhajung Station are shown in Fig. 1. Mapping was done during the field survey with the help of ground photographs. The typical forms of periglacial characteristics are talus, block slopes, rock glacier, block stream, and patterned ground.

\section{Talus, Rock glacier, and Block stream}

Above the snow line, most of the terrain is covered with glaciers, ice body, and firn. Only small parts are exposed as bare bed rock reflecting the humid climate of the East Himalayas. Below 


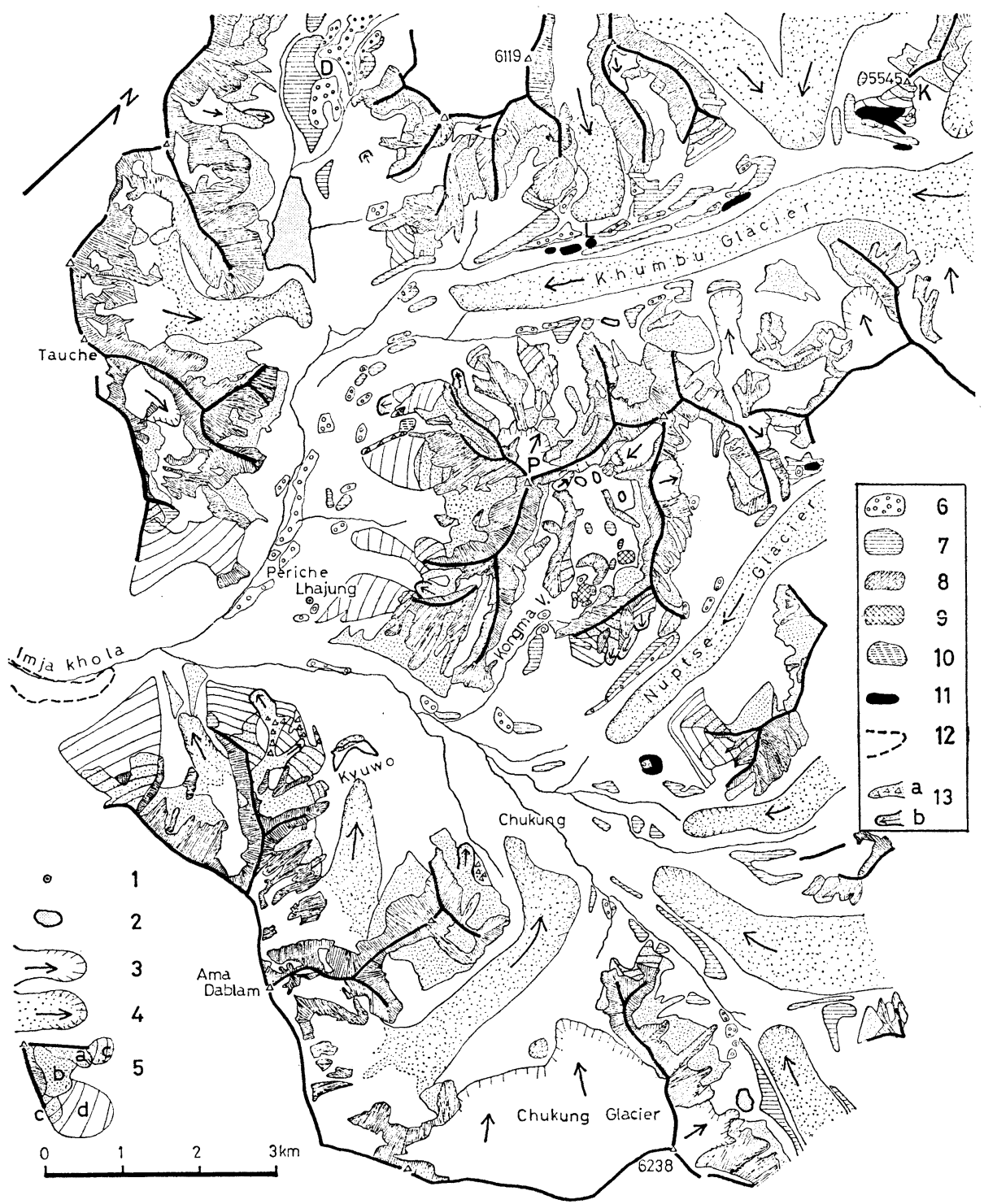

Fig. 1. Distribution of the patterned ground and the periglacial landforms in the Sagarmatha region.

1, Lhajung Station. 2, Pond and lake. 3, Glacier (exposed). 4, Glacier (debris-covered). 5, -a, Rock wall. -b, Talus. -c, Block slope. -d, A slope covered with regolith. 6, Earth hummocks. 7, Vegetated lobes. 8, Sorted patterned ground. 9, Debris islands. 10, Sorted terraces. 11, Vegetated polygons. 12, Forest line. 13, -a, Block stream. -b, Rock glacier. D, Dzonglha, K, Kala Pattar. L, Lobuchee. P, Pokalde.

the snow line down to $5000 \mathrm{~m}$ in altitude, the mountain slopes are occupied by a wide steep rock escarpment from which much detritus is produced by forst shattering, frost wedging, and other weathering processes.

Many talus cones are formed by the accumulation of debris as rock falls from the rock escarpment on cirque floors which were carved at the middle of the valley slope and lateral moraines of the upper valleys. The talus cones, formed far down the escarpment, have inactive features, being covered with vegetation and/or the boulders are weathered and lichen-covered. The rock glaciers and block streams were formed on the cirque floor and lateral moraines where both detritus and snow and ice were accumulated 


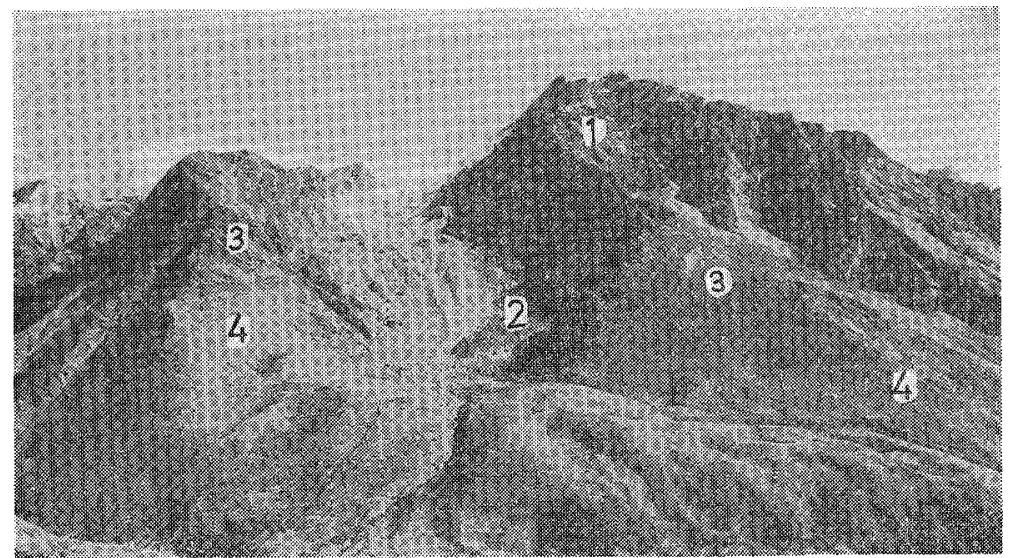

Fig. 2. Periglacial landforms of the west flank of Mt. Pokalde. (5806 m) 1, Rock wall. 2, Rock glacier. 3, Block slope. 4, Regolith-covered slope.

intensitely by rock-falls and avalanches. Some active rock glaciers are situated at the inside of the cirque of the west of Mt. Pokalde and at the foot of the high truncated spur of the south of Chukhung Kharka. Since inactive rock glaciers and block streams consist of thick matrix-free large boulders, it is impossible for vegetation to invade to the surface of them.

\section{Block slopes}

Most of the terminal facets of the ridges facing to the valley are not steep and are covered with angular and sub-angular blocks (Fig. 2). The blocks are coarse, about one meter in diameter, and are free from interstitial fines.

The form of the slope is slightly convex and its inclination is less than $30^{\circ}$. The blocks cover the slope thinly and do not form a block stream on the slope. Such a slope is called a block slope. The coarse and angular debris which compose a block slope is derived from the underlying bed rock by intenisve frost wedging (Washburn, 1973). At present many of these block slopes seem to be inactive; frost wedging does not operate and blocks are not porduced.

There are rock outcrops or tors at the top of the slope and at the end of the lower part of the slope, the blocks represent lobate forms which suggest solifiuction has occured.

Underneath the block slopes, there exist slopes covered with soil and fine material (regolith) and vegetation. The upper part of the slope covered with regolith is the same form and inclination as the block slope above it, but the lower part

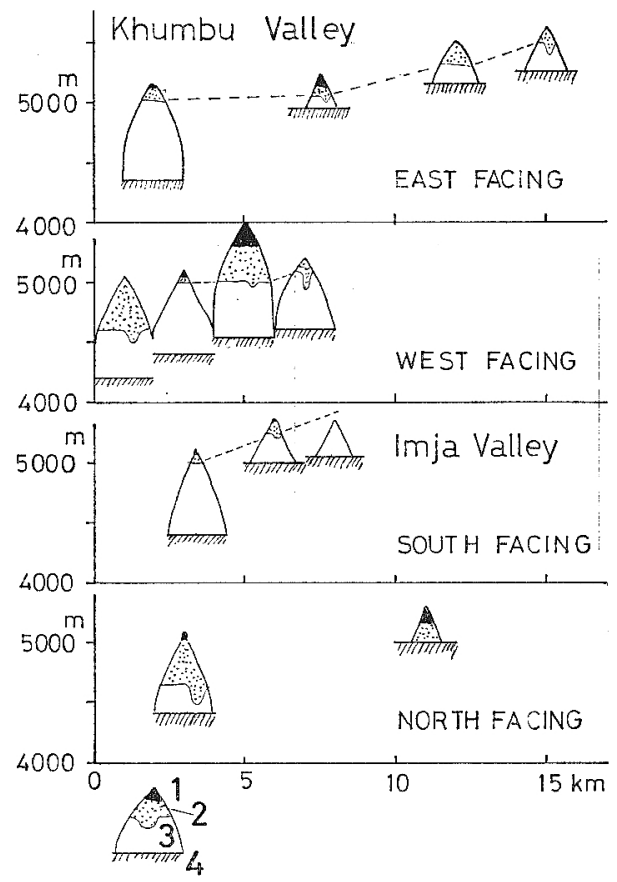

Fig. 3. Vertical arrangements of the block slopes along the Khumbu and Imja valley. 1, Rock wall, tor. 2, Block slope. 3, Regolith-covered slope. 4, Platform, moraine.

of the slope joins to the platform (Iwata, 1976) and the lateral moraines as a concave form. Fig. 3 shows the vertical arrangement of these slopes along the Khumbu and Imja valleys.

The lower limits of the block slopes rise from south to north along the Khumbu valley. The lower limits of the block slopes of the south- 
facing slopes are higher than those of the northfacing slopes in the Imja valley. The surface features of the slopes covered with regoliths are similar to the platform and the moraines were formed in the Last Glacial (Iwata, 1976).

This suggests that the block slopes were formed by intensive frost action against bed rock, soon after the rock was released from the glacier and firn. As soon as the bed rock appeared, the detritus was produced and began to creep downwards as result of intense frost action. After the climate became warmer, the blocks stopped moving. At present, the block slopes are being covered by vegetation slowly from below.

\section{Pattermed grounad}

A detailed discussion on the patterned ground in this region was given by Iwata and others (1976). The vegetated patterned ground, such as earth hummocks, vegetated lobes, turf banked

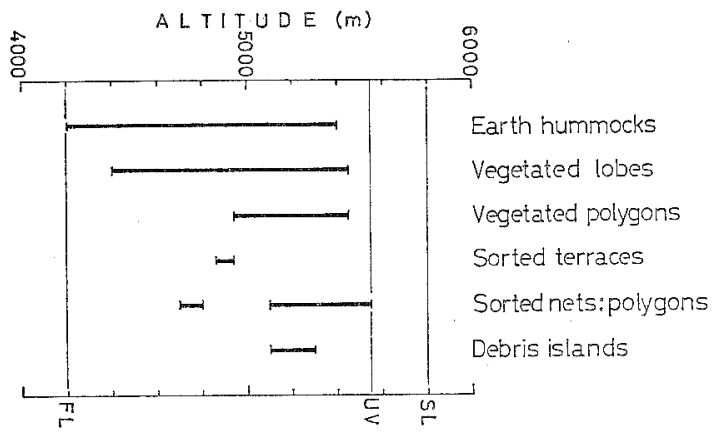

Fig. 4. Vertical distributions of patterned ground in the Sagarmatha region SL: Snow line, UV: Upper limit of vegetation cover, FL: Forest line. (after, Iwata, Fuji, and Higuchi, 1976).

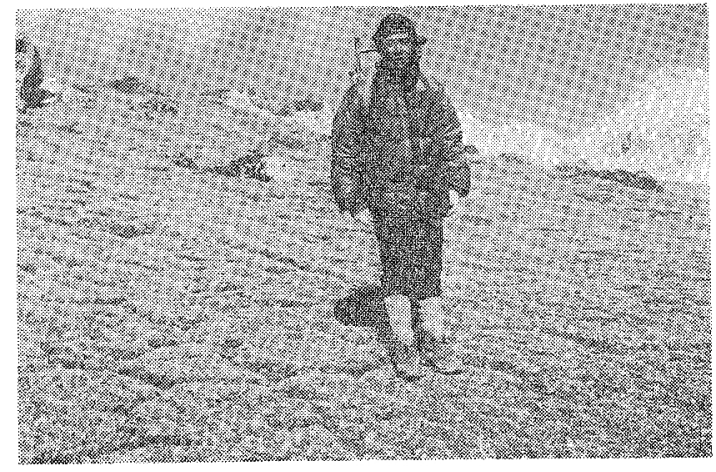

Fig. 5. Vegetated polygonal ground at Kala Pattar $(5300 \mathrm{~m})$. terraces, and ploughing blocks, is widely destributed above the forest line up to the upper limit of the vegetation (Fig. 4). Vegetated polygons (Fig. 5) are found around $5000 \mathrm{~m}$ in altitude.

The development of the vegetated patterned ground is due to abundant rain in summer, which nourishes the vegetation, and to the intense frost action in winter.

Sorted patterned ground occurs in the limited places, such as the bottoms of pond which dry up in autum and winter and the bare ground adjacent to glaciers above $5000 \mathrm{~m}$.

Sorted patterned ground is prevented from forming by dense vegetation cover below 5200$5500 \mathrm{~m}$ and by the steep and rugged terrain, such as rock walls, talus, and block slopes, above that altitude.

The large scale debris islands, $4-5 \mathrm{~m}$ in diameter, situated on the floors of the Kongma valley seem to be inactive. This suggests that some time of the Post Glacial Period, the weather was cooler than now.

Though permafrost has been reported in this region (Fujii and Higuchi, 1976), large scale icewedge polygons have not yet been found.

\section{Conclusion}

The major landforms and phenomena of periglacial character - the talus, block slopes, and the patterned ground have been described.

Some of them are not active at present, but there are many landforms which are being formed at present around the snow line. This suggests that most of the landforms which are not active now were formed by the conspicuous climatic change during the period from the Late Glacial to the Post Glacial.

Also, recent climatic change which was represented by the glacial readvance (Iwata, 1976) is important for some forms.

It is likely that the the most effective method of landform study of the Himalayas is the detailed mapping of all forms of the area and the illustration of them chronologically.

The relationship between the climatic process and the Himalayan uplift will become clear after further intensive studies.

\section{Refarences}

Fujii, Y. and Higuchi, K. (1976): Ground temperature and its relation to permafrost occurrences in the Khumbu region and Hidden Valley, in this issue. 
Gansser, A. (1964): Geology of the Himalayas. Interscience Publishers, London, 289 pp.

Haffner, W. (1972): Khumbu Himalaya, Landschaftsökologische Unterschungen in den Hochtälern des Mt. Everest-Gebietes. In, Troll, C. ed., Geoecology of the High-Mountain Regions of Eurasia, Wiesbaden, 299 pp., 244-263.

Iwata, S. (1976): Late Pleistocene and Holocene moraines in the Sagarmatha region, Khumbu Himal. in this issue.

Iwata, S., Fujii, Y., and Higuchi, K. (1976): Nepal Himalaya no kôzôdo (Patterned ground of the
Nepal Himalayas,). Journal of Geography, 85, 143161.

Kar, N.R. (1969): Studies on the geomorphic charactristics and development of slopes in the periglacial zones fo Sikkim and Darjeeling Himalaya. Biultyn Peryglacialny, nr. 18, 43-57.

Ohta, Y. and Akiba, C., ed., (1973): Geology of the Nepal Himalayas. Himalayan Commitee of Hokkaido University, 286 pp.

Washburn, A.L. (1973): Periglacial processes and environments. Edward Arnold, London, 320 pp. 